\title{
Introduction
}

Uber - an app that links private taxi drivers with customers - has encountered several roadblocks around the world: a Brussels court banned it, a Berlin court ruled that the taxis are rental cars and must therefore return to their place of business between each fair, Paris briefly instituted a rule that an Uber cab had to wait for 15 minutes before picking up a passenger regardless of how far apart the two initially were, and the company has run into similar bumps in the road in several American cities.

At the same time, New York City, Paris and Berlin, are all restricting the use of Airbnb, an app analogous to Uber, but for short-term rental of private apartments. In New Jersey the sale of Tesla electric cars might soon come to a halt because of an obscure ruling mandating that cars should be sold through independent car dealers and not directly from producer to consumer as Teslas are.

Why such zeal from local city halls and court rooms in regulating the conduct of business? It seems that this is just the latest installment of the age-old wheel of 'creative destruction': whenever a new product or service is invented - whatever may be its benefits - there will be both winners and losers. One could argue that it is the job of politicians everywhere to balance the costs and benefits of new innovations and block those that do not benefit society as a whole. And that the consequences for those who have long been employed as taxi drivers, in the case of Uber, should be given extra weight. It seems that in practice, however, the interests of the incumbent taxi companies, hotel owners and car dealerships have much greater weight than the potential gain to local consumers and new companies. As Mr. Leipold, the chairman of Berlin's taxi association, put it, 'This isn't a student start-up against a big taxi cartel. Uber is backed by Google. If I'm wearing gym shorts, I don't want to compete against someone wearing hobnailed boots.'

If incumbents indeed believe they have the right to only compete against student start-ups it seems we might have too little and not too much 'creative destruction.' (Morten Olsen 2014) ${ }^{1}$

Creative destruction, disruptive innovation, potentially revolutionary business models and regulation stopping them: that is what Olsen's blog is about. And it is also what this book is about.

Creative destruction is a force in economic development first described by the Austrian-American economist Joseph Schumpeter (1883-1940) and developed in detail by the American economist and business scholar 
Clayton M. Christensen (born 1952). Since the emergence of the digital economy, creative destruction is a widely used term. However, creative destruction and regulation more often than not are at odds with each other. Some economists would push this claim even further. They would say that creative destruction and regulation are by necessity natural opposites. The reason is that while creative destruction is about innovation, or the advancement of new ideas turning them into new products, or business models, thus challenging the status quo of the markets, regulation is about perpetuating this status quo. In the case of Uber, the creative destruction it is supposed to unleash is being stopped by regulation that prefers traditional taxicab providers.

Granted, regulation often envisages maintaining or enhancing the wellbeing or at least the welfare of a society. However, very often regulation fails to achieve this aim and even more often it falls prey to special interests. These, again, are mostly about preserving the status quo. Also here some economists would push the claim further than this. They would say that even if regulation maintains the wellbeing of a society by continuing the present state of affairs, this continuation is detrimental to possible future gains in welfare and wellbeing. When regulation in the short-sighted interest of the present prevents creative destruction from happening, it does so at the expense of future developments. In sum, by privileging the present over the future, regulation opposes innovation.

Uber illustrates this intuition very well. Most of those protesting Uber worldwide do not demand any new regulation. They just call for the existing regulation to be applied to Uber. As local regulators decide about that, they either make Uber comply with existing regulation or they outlaw Uber simply because it is not a taxicab company as regulators know them. No regulator explicitly sets out to curb innovation in the taxi business, but because of the static and backward-looking character of regulation, regulators tend to block the innovator.

Naturally, regulation and regulators don't explicitly claim that opposition to innovation is the goal of their actions, ${ }^{2}$ so it becomes difficult to make a case for them actively undermining it. But there is implicit opposition, as the example of Uber shows. This means there are side effects of regulatory activity that are detrimental to innovation. The question, then, is if these side effects can be avoided. If they are a natural part of any regulation, they cannot. From the economic point of view taken here, there are two good reasons, maybe even three, for believing that these side effects are implicit components of - possible all regulatory activities. They have been hinted at above. 
First, regulation is static in nature and prefers the static over the dynamic. This is not a normative claim and it is not meant pejoratively. To state that regulation prefers the static amounts to saying that it is geared toward judging state of affairs and not processes of innovation. By definition, regulation remains unchanged in order to ensure legal certainty and stability. Also by definition, regulation and regulators, when judging facts, interpret them as a function of the static regulation to which they are committed. Call this their frame of reference. This leads to them transforming dynamic developments into static snapshots and interpreting these in the light of static rules. Innovation, as the result of a series of dynamic processes, escapes this mechanism. There is no guarantee - not even plausibility - that a given snapshot can be representative of the whole innovative dynamic. Regulation, therefore, is not suited to deal with innovation because of its static point of view. Apply this to the example of Uber: without taking into consideration what gains consumers and the taxicab industry itself could have from Uber's innovation, regulators decided to look at a snapshot. This shows Uber as an unregulated taxi business competing against regulated service providers. The main point of Uber, however, is missing in this picture: innovation on the level of process, technology, sourcing and quality.

Second, regulation is backward looking. Again, this is not a normative claim and it is not meant pejoratively. To state that regulation is backward looking amounts to saying that past knowledge is its own frame of reference. It has been set up in the past and reflects, therefore, past knowledge and past regulatory intent. Because of the manner regulation is made it cannot incorporate future developments, including innovation. Even if regulation is changed, it is still changed in a backward-looking way, since adapting it to actuality does not mean adapting it to the future - for the future is unknown. Regulators don't know what tomorrow will bring. Regulations and regulators in judging or regulating innovation by current standards, models and methods automatically give preference to what they already know. And that is the status quo. Granted, no one knows how the future is going to unfold. But the difference between regulators and all other participants of a society is while average participants don't take it upon themselves to decide how a society will or should develop, regulators are often in the position of making decisions about it, or at least their decisions have consequences for the future. While regulators have the power to influence the future, it is debatable if they really can know more about it than the average members of a society. Apply this to the example of Uber: regulators compared the novelty - Uber - to what they were accustomed to traditional taxicabs. Using their current, backward-looking knowledge 
about taxicabs, the regulators barred Uber because it was not a traditional taxicab company. Or they made Uber convert to one in order to make it fit into their backward-looking frame of reference. In doing this, they are imposing the past on the future.

There might even be a third reason for regulation being implicitly opposed to innovation. That is the role of vested interests. Regulation often protects those companies that are already active in a given market over newcomers. This can happen explicitly, when regulation is developed in dialogue with the regulated entities, or implicitly, when the regulated firms constitute the frame of reference for setting up regulation. It is easier to develop regulation by calling the active taxicab companies to a roundtable and discussing with them rather than to do it on the drawing board. And even if the drawing board approach is taken, most regulators first survey the actual status of the industry they want to regulate. Both these methods lead to a preference for insiders over outsiders. Apply this to the example of Uber: in most cities and regions where Uber has been banned, there are institutionalized dialogues between regulators and taxi companies. Uber, however, does not sit at that roundtable.

This third reason for the opposition of innovation and regulation leads to an interesting problem in the dynamic view: What is the role played by participants in markets (or, as economists like calling them, agents)? Often, market agents begin as innovators and drivers of creative destruction, but once they gain a standing in the markets, they develop an interest for protecting their achievements. More often than not, these agents seek regulation as protection in order to solidify their position and prevent even newer innovators from challenging their products. It is not uncommon for those seeking regulation to advance arguments like consumer protection, job security or, as the blog at the beginning of this introduction states, the narrative of David fighting Goliath ${ }^{3}$ in order to give their special interests a broader and more social foundation.

What does this tell us? Market agents are not passive bodies pushed by the forces of creative destruction and regulation; they are a force in themselves tending toward the one or the other, as it best suits their interests. It may even be that a given agent has a commitment toward innovation in its mission statement and vision; however, this does not prevent this agent from changing the role it plays. Even a company committed to innovation can start lobbying regulators for more regulation, especially to bar newcomers from joining the market and destroying its established business model. So, it is not about what individual agents claim to prefer, it is about what they actually do, or the role they actually play. ${ }^{4}$ As the philosopher Henry Rosemont (2015) put it: 'Role is self.' 
Does this mean that all those companies - Uber, Airbnb, Tesla portrayed by Olsen in his blog as suffering setbacks today because of regulation might embrace it tomorrow? Potentially, not: probably, yes. Does it also mean that some consumers who now hail the advent of those business models might one day change their minds? Possibly, yes. And why is that so? Because markets, more precisely all agents in markets, are in constant change about what they want and what they perceive desirable. Markets are a series of dynamic processes. For this reason, it is not possible to write about Uber, or about the sharing economy, without taking a closer look at the market processes that are behind them. This book is asking questions about Uber, the sharing economy, creative destruction or if regulation is sorting out different processes that occur at the same time but with different directions.

\section{WHAT IS THIS BOOK ABOUT?}

This is a book about Uber. More precisely it is about Uber as a case study for the economics of the relation between creative destruction and regulation. So, this book is about innovation - treated here under the concepts of creative destruction and disruptive innovation - regulation with a focus on sectorial regulation and competition regulation - and, yes, Uber, and more generally the sharing economy.

The book narrates the following story: while creative destruction and disruptive innovation change the entrepreneurial landscape, regulation, especially regulation of sectorial markets and competition regulation, delays this change or even brings it to a halt. Uber, as a participant of the market, is not just an object moved by these two opposing forces. It plays an active role, first as an agent of creative destruction and then possibly in championing regulation on its own terms.

In order to narrate this story, the book touches on a number of questions within economics and its relationship to regulation. Grounded in a particular understanding of the economic concept of the market as a series of processes (see the detailed discussion in Chapter 1), the book relies on economic theory in order to discover the implications of creative destruction, competition regulation and the role that businesses, or market agents, play. It is committed to interdisciplinary thinking, so it also relies on philosophy, jurisprudence, sociology and even history. Instead of discussing these relations in a purely abstract manner, the book uses Uber as a case study. Uber makes these abstract problems tangible and helps, maybe, in recognizing general patterns. 
The relationship between Uber, regulation and innovation is by far not the only issue that can be raised by what is often referred to as the Uber phenomenon at least using Uber as a case study. Some examples for these other questions are: Uber's behavior as an economic agent has consequences on people and other companies as well as on the economy and society as a whole. Also, Uber has been treated as a token for the sharing economy, an economic model in which individuals are able to borrow or rent assets owned by someone else. And even more generally, Uber and the sharing economy are often hailed as the ultimate gamechangers in capitalism. These are very broad questions about social philosophy, business ethics and the nature of our economic exchanges assuming there is anything like this. Although these questions are not at the center of this book, they must be addressed: Chapter 1 will examine the question about the often-claimed revolutionary nature of the sharing economy. Chapter 2 discusses Uber's business model and will at least point toward some of the social and ethical implications it might have.

The book focuses on Uber as a case study for analysing and explaining two opposite forces: innovation and regulation. These forces are antagonistic because regulation often delays or stops innovation. Innovation itself can be understood in different ways: there can be technological innovation or just innovative marketing of products; there is innovation in industrial production as well as innovation in organization, among others. The case of Uber shows that a company can pursue different types of innovation at the same time. Maybe the case of Uber shows that the more diversified a company innovates, the stronger agent of creative destruction it becomes.

But regulation has different facets. Regulation can be broadly understood as the entirety of a legal system. It can also be thought of as sectorial regulation envisaging setting standards, for example, for the quality of services provided or the security of customers. Regulation can also be about some types of market processes, for example, about competition. The case of Uber shows that regulation can be an amalgamation of all three. However, sectorial regulation and competition regulation impact Uber the most. So this book will focus on these two aspects. Maybe the case of Uber shows that the finer-grained the regulation, the more adverse effects on innovation it creates.

Finally, there is the role that companies play between innovation and regulation. Even Uber seems to be adapting to regulation. This leads Uber to change its business model and value propositions. Maybe the case of Uber shows that the more innovators adapt to regulation, the more vulnerable they become to creative destruction by even newer agents with even more disruptive innovation. 


\section{THE WAY FORWARD}

The book consists of four chapters. Each is dedicated to a leading question. All chapters share the same basic structure. First, the question is outlined, then it is discussed using the framework of economic theory. Finally, the results of the discussion are applied to Uber. Each chapter ends with a summary that is the answer to the leading question. The four chapters and their leading questions are:

- What is the economics of Uber (and this book)? It has been mentioned above that this book understands markets as processes; as an open-ended multi-polar series of exchanges. This understanding requires a more detailed explanation. This explanation also helps in understanding how this conception of the market as processes differs from the conception of markets that most regulators share, which is considering them an institution. This explanation sets the theoretical ground for investigating the relation between innovation and regulation. Then, the chapter provides an overview on the special setting of Uber as an economic phenomenon. This setting is often referred to as the sharing economy. The first chapter of the book discusses what might be new about the sharing economy and how it might be different from other, usual markets.

- What is Uber's business model? The second chapter of the book is Uber-specific. Without going into too much detail, the most important aspects of Uber as a company, its strategy and business model are explored. Its technology, unique features, diversification of product lines and market penetration tactics are at the center of this chapter. After all, it is about showing on what levels Uber innovates. Also, this chapter contains a brief history of the taxicab industry and its regulation, which helps highlight the specific differences of Uber. This brief history also helps in understanding why taxicab regulation is as it is today.

- How is Uber an agent of creative destruction? In the third chapter, two distinct but complementary ideas of innovation are discussed: Schumpeter's creative destruction and Christensen's disruptive innovation. So much has been written about them that it is the aim of this chapter to go back to the roots, back to the original texts. While Schumpeter came up with the idea of creative destruction, it was Christensen that made it operational. After explaining both theories, the chapter applies them to the case of Uber. 
- How opposite are innovation and regulation? The fourth chapter provides a more detailed survey of the relation between innovation and regulation. It asks which arguments for regulation can be put forward and how their respective economics work. In particular, it looks at how the economics of so-called pro-competitive regulation impacts innovation. Special attention is given to sectorial regulations and the regulation of competition. After this discussion, the idea of regulation and innovation opposing each other is applied to Uber's case. How Uber changes its business model because of regulation - in order to accommodate it - is explored. But, on the other hand, it is also shown that some regulations are starting to change in order to accommodate Uber.

After these four chapters, a conclusion asks the last question: Who is or will be destroying Uber, the disruptor? Here the focus is on the role of market agents, especially about how Uber changed its role and how it might start to play the regulatory game. If it starts, then other agents will try to innovatively disrupt Uber.

With this approach, each chapter can be read on its own or used in a classroom situation. Also, with this approach, the reader advances through different parts of economic theory and different stages of Uber's development (so far). Continuously mirroring economic theory on Uber reveals the double intent of this book: it is a book on Uber and it is a book on economics.

\section{NOTES}

1. While the relevant academic references are quoted in the reference section, news and blogs are referred to in these notes. Olsen, M. (2014), 'The fight against creative destruction,' accessed 20 May 2016 at http://blog.iese.edu/economics/2014/04/23/the-fight-againstcreative-destruction.

2. But the author of this book attended a podium in France in March 2015 during which a competition regulator said 'Everything that had to be invented, exists already.'

3. In its broad meaning, the story is about an underdog situation, a contest where a smaller, weaker opponent faces a much bigger, stronger adversary, and wins. The biblical story with a different and religious intention - can be found in 1 Samuel 17.

4. See, for a non-Uber example, the strange case of the Swiss bank Credit Suisse. This bank is openly committed to innovation. On its strategy papers, it claims that 'innovation is a must.' And even in practice, Credit Suisse is an incremental innovator. However, its Chairman of the Board, Urs Rohner, in 2015 openly demanded a worldwide regulation of all banks. It seems strange for a bank to call for more regulation. But the rationale behind it is simple once revealed: due to its large structure - Credit Suisse is one of the largest banks on the planet - it would be cheaper for this bank to implement regulation than for other banks. The scale of its structure diminishes average costs of compliance. Credit Suisse would have a competitive advantage over other banks because of regulation-induced costs. So, here, 
Credit Suisse plays the role of a market agent preferring regulation over its own commitment to innovation. The irony is that Credit Suisse could compete with other agents on quality, price or innovation, but prefers to compete using regulation-induced costs. For Credit Suisse's commitment to innovation, see Credit Suisse (2016), 'Innovation in the service of clients,' accessed 20 May 2016 at https://www.credit-suisse.com/cl/en/about-us/ who-we-are/history/innovation.html. For Rohner's comments, see the podium at the World Economic Forum 2015 in Davos, for example, in https://www.youtube.com/watch?v= 4ZkvsuRp4dM (marks 16:07 and 55:20; accessed 20 May 2016). 